\title{
Leptin signalling in pancreatic islets and clonal insulin-secreting cells
}

\section{N M Morton ${ }^{1}$, V Emilsson ${ }^{1}$, R P de Groot ${ }^{2}$, A L Pallett ${ }^{1}$ and M A Cawthorne ${ }^{1}$}

${ }^{1}$ The Clore Laboratory, The University of Buckingham, Buckingham, Buckinghamshire, MK18 1EG, UK

${ }^{2}$ The Department of Pulmonary Diseases, University Hospital Utrecht, PO Box 85500, 3508 GA Utrecht, The Netherlands

(Requests for offprints should be addressed to M A Cawthorne)

(N M Morton is now at Department of Molecular Endocrinology, Molecular Medicine Centre,

Western General Hospital, Edinburgh, UK)

\begin{abstract}
Leptin is a cytokine secreted from adipose tissue at a rate commensurate with the size of the body's fat stores. In addition to its anorectic and thermogenic central actions, leptin is known to act on peripheral tissues, including the pancreatic $\beta$-cell where it inhibits insulin secretion and reduces insulin transcript levels. However, the role of leptin signalling through its full-length receptor, OB-Rb, in the $\beta$-cell remains unclear. In the present study, we show that leptin activates a signal transducer and activator of transcription (STAT)3 signalling mechanism in pancreatic islets and in a rat model of the pancreatic $\beta$-cell, RINm5F. Leptin induced DNA binding to a STAT consensus oligonucleotide and resulted in transcriptional activation from STAT
\end{abstract}

reporter constructs in a manner consistent with STAT3 activation. Western blot analysis confirmed activation of STAT3 in RINm5F and isolated rat islets. Conditions that mimic increased metabolic activity resulted in attenuation of leptin-mediated STAT DNA binding but had no significant effect on STAT3 tyrosine phosphorylation in RINm5F cells. In addition, leptin activated the mitogen activated protein (MAP) kinase pathway in RINm5F cells. The present study provides a framework for $\mathrm{OB}-\mathrm{Rb}$ signalling mechanisms in the programming of the $\beta$-cell by leptin and suggests that increased metabolic activity may modulate this function.

Fournal of Molecular Endocrinology (1999) 22, 173-184

\section{INTRODUCTION}

Leptin, a hormone secreted from white adipose tissue (Zhang et al. 1994) in direct relation to the size of total fat mass (Maffei et al. 1995), regulates body weight homeostasis through anorectic and thermogenic mechanisms (Campfield et al. 1995, Pelleymounter et al. 1995). In addition, it has now been demonstrated in many laboratories that leptin inhibits insulin secretion from mouse, rat and human pancreatic islets (Chen et al. 1997, Emilsson et al. 1997, Fehmann et al. 1997a, Kieffer et al. 1997, Kulkarni et al. 1997, Pallett et al. 1997, Ookooma et al. 1998, Poitout et al. 1998). Furthermore, leptin reduces insulin transcript levels in rat islets (Kulkarni et al. 1997, Pallett et al. 1997). The possible importance of leptin in control of $\beta$-cell function in vivo is underlined by the fact that leptin- and functional leptin receptor-deficient mice (ob/ob and $d b / d b$ respectively) exhibit early onset hyperinsulinaemia, obesity and non-insulindependent diabetes mellitus (NIDDM) (Coleman 1978, Zhang et al. 1994, Chen et al. 1996). Chronic daily leptin administration to $o b / o b$ mice leads to a reduction in plasma insulin and glucose levels too rapidly to be accounted for by the changes in body weight (Campfield et al. 1995, Halaas et al. 1995, Pelleymounter et al. 1995). Moreover, it has been demonstrated that a single injection of leptin into $o b / o b$ and normal-fed mice produces an acute reduction in plasma insulin levels, indicative of a direct action on the $\beta$-cell (Kulkarni et al. 1997). These findings have led us and others to postulate that the high levels of leptin that occur in obese individuals may exert an inappropriate inhibitory action on $\beta$-cell insulin secretion and contribute to the development of NIDDM (Emilsson et al. 1997, Kulkarni et al. 1997, Pallett et al. 1997). 
Several recent studies have addressed the mechanism whereby leptin exerts its inhibitory action on $\beta$-cells. Thus there is evidence to suggest that leptin can hyperpolarize the $\beta$-cell by directly acting on the ATP-sensitive potassium channels (Harvey et al. 1997, Kieffer et al. 1997). Leptin also lowers the intracellular free calcium concentration $\left(\left[\mathrm{Ca}^{2+}\right]_{\mathrm{i}}\right)$ (Fehmann et al. 1997a,b, Kieffer et al. 1997) and chronic exposure to leptin results in intra-islet triglyceride depletion, thus rendering the $\beta$-cell unresponsive to nutrients (Koyama et al. 1997, Shimabukuro et al. 1997, Wang et al. 1998). The combined action of leptin on cellular membrane potential, $\left[\mathrm{Ca}^{2+}\right]_{\mathrm{i}}$ and triglyceride stores could explain the observed acute inhibitory effects of leptin on insulin secretion and the longer-term reduction in insulin transcript levels. Although leptin has been shown to act through its full-length receptor, OB- $\mathrm{Rb}$, to activate the Janus kinase (JAK) and signal transducer and activator of transcription (STAT) pathway in a number of systems (Baumann et al. 1996, Ghilardi et al. 1996), OB-Rb signalling in pancreatic islets has not been defined. In the present study we present evidence that the effects of leptin are mediated by a STAT3 mechanism in primary rat islets and through STAT3 and mitogen activated protein (MAP) kinase in RINm5F $\beta$-cells.

\section{MATERIALS AND METHODS}

\section{Cell culture}

RINm5F cells were a gift from Dr S Islam (Rolf Luft Centre, Karolinska Institute, Stockholm, Sweden). Cells were routinely cultured in $25 \mathrm{~cm}^{2}$ flasks in RPMI-1640 medium (Gibco BRL, Paisley, Strathclyde, UK) supplemented with $100 \mathrm{U} / \mathrm{ml}$ penicillin, $100 \mu \mathrm{g} / \mathrm{ml}$ streptomycin, $2 \mathrm{mM} \mathrm{L-}$ glutamine, $5.6 \mathrm{mM}$ glucose and $10 \%$ fetal calf serum at $5 \% \mathrm{CO}_{2}$ in a humidified $37^{\circ} \mathrm{C}$ cabinet. Flasks were pre-incubated for a minimum of $24 \mathrm{~h}$ in serumfree $(0 \cdot 1 \%$ BSA) RPMI-1640 before exposure to recombinant murine leptin (Peprotech, London, $\mathrm{UK}$ ), forskolin/3-isobutyl-1-methylxanthine (IBMX), acetylcholine or ionomycin (all from Alexis Corp., Nottingham, UK) for the indicated times and concentrations in serum-free RPMI-1640. Serumfree pre-incubation was necessary to reduce basal STAT3 activation and to remove activity of residual leptin present in the routine culture medium, as described previously (Islam et al. 1997).

\section{Nuclear extracts}

After treatment, the cells were washed in ice-cold PBS, and then in ice-cold PBS with phosphatase inhibitors $\left(1 \mathrm{mM} \mathrm{Na} \mathrm{VO}_{4}, 5 \mathrm{mM} \mathrm{NaF}\right)$. Cells were lysed in a hypotonic buffer (20 mM Hepes, $\mathrm{pH} 7 \cdot 9$, $20 \mathrm{mM}$ NaF, $1 \mathrm{mM}$ EDTA, $1 \mathrm{mM}$ EGTA, $10 \mathrm{mM}$ $\mathrm{Na}_{2} \mathrm{MoO}_{4}, 1 \mu \mathrm{M}$ microcystin LR (Alexis Corp.) with protease inhibitors (Boehringer Mannheim Complete Mini Protease Pellets, Boehringer Mannheim, Mannheim, Germany) and $0 \cdot 2 \%$ IGEPAL detergent (Sigma Chemical Co., Poole, Dorset, UK). Nuclei were collected by brief centrifugation at $14000 \mathrm{~g}$ and the pellet resuspended in a high-salt buffer (hypotonic buffer with $0.42 \mathrm{M} \mathrm{NaCl}$ and $20 \%$ glycerol, without IGEPAL). Nuclear proteins were extracted for $30 \mathrm{~min}$ at $4{ }^{\circ} \mathrm{C}$ by rotation before sedimentation of debris at $14000 \mathrm{~g}$ for $20 \mathrm{~min}$. Nuclear extract supernatants were snap-frozen in liquid nitrogen and stored at $-80{ }^{\circ} \mathrm{C}$ before we undertook gel-shift assays. A kit was used to determine protein concentration, according to the manufacturer's data sheet (Sigma Diagnostics P5656 Protein Assay).

\section{Isolation of islets and islet nuclear extracts}

Pancreatic islets were isolated from male Wistar rats of 200-250 g (Harlan Olac, Bicester, Oxon, UK) by collagenase (Sigma type XI) digestion of pancreata in a physiological saline solution as described previously (Pallett et al. 1997). Groups of 200-500 islets were washed in RPMI-1640, 0.1\% BSA and incubated for $6 \mathrm{~h}$. Islets were then collected and re-suspended in RPMI-1640, $0 \cdot 1 \%$ BSA with or without leptin. After the incubation, islets were collected by brief centrifugation and put on ice. Five hundred microlitres ice-cold hypotonic buffer $(10 \mathrm{mM}$ Hepes pH 7.9, $10 \mathrm{mM} \mathrm{KCl}, 1 \mathrm{mM}$ EDTA, $1 \mathrm{mM}$ EGTA, $1 \mathrm{mM}$ dithiothreitol (DTT), $10 \mathrm{mM} \mathrm{NaF}, 10 \mathrm{mM} \mathrm{Na} \mathrm{NoO}_{4}, 10 \mathrm{mM}$ $\beta$-glycerophosphate, $10 \mathrm{mM} \quad \mathrm{Na}_{3} \mathrm{VO}_{4}, \quad 10 \mathrm{mM}$ $p$-nitrophenylphosphate, $1 \mu \mathrm{M}$ microcystin LR) and one tablet per $10 \mathrm{ml}$ Complete Mini Protease Inhibitor (Boehringer Mannheim) were added to the islets on ice. After $15 \mathrm{~min}, 25 \mu \mathrm{l} 10 \%$ IGEPAL were added and the islets vortexed briefly. Nuclei were collected by centrifugation at $14000 \boldsymbol{g}$ for $20 \mathrm{~s}$ and the pellet re-suspended in $50 \mu \mathrm{l}$ high-salt buffer (hypotonic buffer with $0.4 \mathrm{M} \mathrm{NaCl}$ and $5 \%$ glycerol) and one tablet per $10 \mathrm{ml}$ Complete Mini Protease Inhibitor. Debris was removed by centrifugation at $14000 \mathrm{~g}$ for $10 \mathrm{~min}$ and the supernatant extracts taken for gel-shift.

\section{Mobility-shift assay}

The gel-shift assay was performed with oligonucleotides from the c-fos promoter (a mutated c-sis inducible element, m67SIE) top strand 5'-CAT 
TTC CCG TAA ATC AT-3' and rat $\beta$-casein promoter, top strand 5'-GGA CTT CTT GGA ATT AAG GGA-3'. STAT-binding elements are underlined. These were end-labelled with $\left[\gamma_{-}{ }^{32} \mathrm{P}\right] \mathrm{ATP}$ (Amersham, Little Chalfont, Bucks, UK) and T4 polynucleotide kinase (Gibco). Binding reactions included $1 \mathrm{mM}$ DTT, $1 \mu \mathrm{g} / \mathrm{ml}$ polydI:polydC (Pharmacia, Uppsala, Sweden), 10\% glycerol and $10 \mathrm{mM}$ Tris, $\mathrm{pH}$ 7.9. The mixture was incubated at room temperature for $20 \mathrm{~min}$ and protein-DNA complexes were separated on $4 \%$ native polyacrylamide gels containing 5\% glycerol. Gels were dried under vacuum for $40 \mathrm{~min}$ and then exposed to Kodak Biomax film (Sigma) at $-80{ }^{\circ} \mathrm{C}$ overnight.

\section{Western blot}

Nuclear extracts were obtained as described above. An equal volume of $2 \times$ sample-loading buffer (100 mM Tris, pH 6·8, 10\% SDS, 20\% glycerol, $2 \%$ $\beta$-mercaptoethanol, $0 \cdot 2 \%$ bromophenol blue) was added to the extracts and the samples boiled for $3 \mathrm{~min}$. Samples were separated on 10\% SDS-PAGE gels and transferred to polyvinylidene fluoride (PVDF) membranes (Millipore, Bedford, MA, USA). Antibodies used were STAT3 N-terminal specific (S21320, Transduction Labs, Lexington, KY, USA), anti-phospho-STAT3 Y705 and antiphospho-MAP kinase Y204 (9131S, New England Biolabs, Hitchin, Herts, UK).

\section{Constructs and transcriptional reporter assays}

Chloramphenicol acetyl transferase (CAT) reporter constructs were used. These were: GAS-CAT, containing four copies of the human Fc $\gamma \mathrm{RI}$ interferon- $\gamma$ activated sequence, GAS (5'-AGC TTG AGA TGT ATT TCC CAG AAA AGA-3'), IRE-CAT, containing four copies of the human intercellular adhesion molecule-1 (ICAM-1) interferon- $\gamma /$ interleukin- 6 response element, IRE (5'-AGC TTA GTT TCC GGG AAA GCA C-3'), and $\beta$-casein-CAT, containing four copies of the $\beta$-casein STAT-binding site, $\beta$-CAS (5'-AGC TTA GAT T TC TAG GAA TTC AAA TCA-3'). STAT-binding sites were cloned into the thymidine kinase (TK)-CAT vector pBLCAT2 using a method described previously (Caldenhoven et al. 1996). For transfection experiments, cells were split 1:3 and $24 \mathrm{~h}$ later transfected with $10 \mu \mathrm{g}$ supercoiled plasmid DNA by the DEAE-dextran technique. Briefly, DNA precipitates were prepared by mixing the DNA with $1 \mathrm{ml}$ of $0.5 \mathrm{mg} / \mathrm{ml}$ DEAE-dextran solution (Pharmacia) in Tris-buffered saline (TBS). Cells were washed twice with TBS, after which the cells were exposed to the DNA precipitate for
$30 \mathrm{~min}$ at room temperature. After washing the cells twice with TBS, medium was added with $0.1 \mathrm{mM}$ chloroquine, and the cells were incubated for $6 \mathrm{~h}$ at $37^{\circ} \mathrm{C}$. Cells were then washed twice with PBS, and fresh medium was added. Twenty-four hours later cells were serum starved for $16 \mathrm{~h}$, after which they were stimulated for $12 \mathrm{~h}$ with leptin or vehicle and subsequently harvested for CAT assay. Cells were lysed by repeated freeze thawing in $250 \mathrm{mM}$ Tris, pH 7·4, $25 \mathrm{mM}$ EDTA. Fifty microlitres of cellular extract were then incubated in a total volume of $100 \mu \mathrm{l}$ containing $250 \mathrm{mM}$ Tris, $\mathrm{pH} \quad 7 \cdot 4, \quad 2 \%$ glycerol, $0.3 \mathrm{mM}$ butyryl coenzyme $\mathrm{A}$ and $0.05 \mu \mathrm{Ci}$ $\left[{ }^{14} \mathrm{C}\right]$ chloramphenicol for $2 \mathrm{~h}$ at $37^{\circ} \mathrm{C}$. Reaction products were then extracted using $400 \mu \mathrm{l}$ xylene: pristane $(1: 2)$ and the percentage of acetylated products determined using liquid scintillation counting.

\section{RESULTS}

\section{Leptin induces STAT DNA binding in nuclear extracts from RINm5F and isolated rat islets}

Leptin treatment of RINm5F cells caused induction of a single STAT DNA binding complex with the m67SIE oligonucleotide (Fig. 1). This probe contains a mutated STAT-binding site from the human c-fos promoter and has a high affinity for STAT3 and STAT1. Induction was apparent in RINm5F nuclear extracts by $15 \mathrm{~min}$ and continued to increase up to the $30 \mathrm{~min}$ time point. In experiments using nuclear extracts from isolated rat pancreatic islets, leptin induced a single STAT DNA binding complex using the m67SIE probe that was dose dependent over the concentration range $0 \cdot 2-20 \mathrm{nM}$ (Fig. 2, left panel) in a $15 \mathrm{~min}$ incubation. Time course studies in pancreatic islets showed that induction of this single complex was observed by $2 \mathrm{~min}$, peaked by $15 \mathrm{~min}$ and returned to basal levels by $30 \mathrm{~min}$ (Fig. 2, right panel).

\section{Leptin induces STAT3 activation in RINm5F and isolated rat islets}

Crude cell and nuclear extracts from leptin-treated RINm5F cells were probed with an anti-phosphoY705 STAT3 antibody. Leptin produced a timedependent tyrosine phosphorylation and nuclear translocation of two immunoreactive STAT3 species (Fig. 3a). The rapidly induced more slowly migrating band at approximately $90 \mathrm{kDa}$ is consistent with STAT3 $\alpha$. The faster migrating band is consistent with STAT3 $\beta$ and was induced by 15 min in crude RINm5F cell extracts. This suggests differential activation of the two isoforms 


\section{RINm5F nuclear extracts}

$$
\text { m67SIE probe }
$$

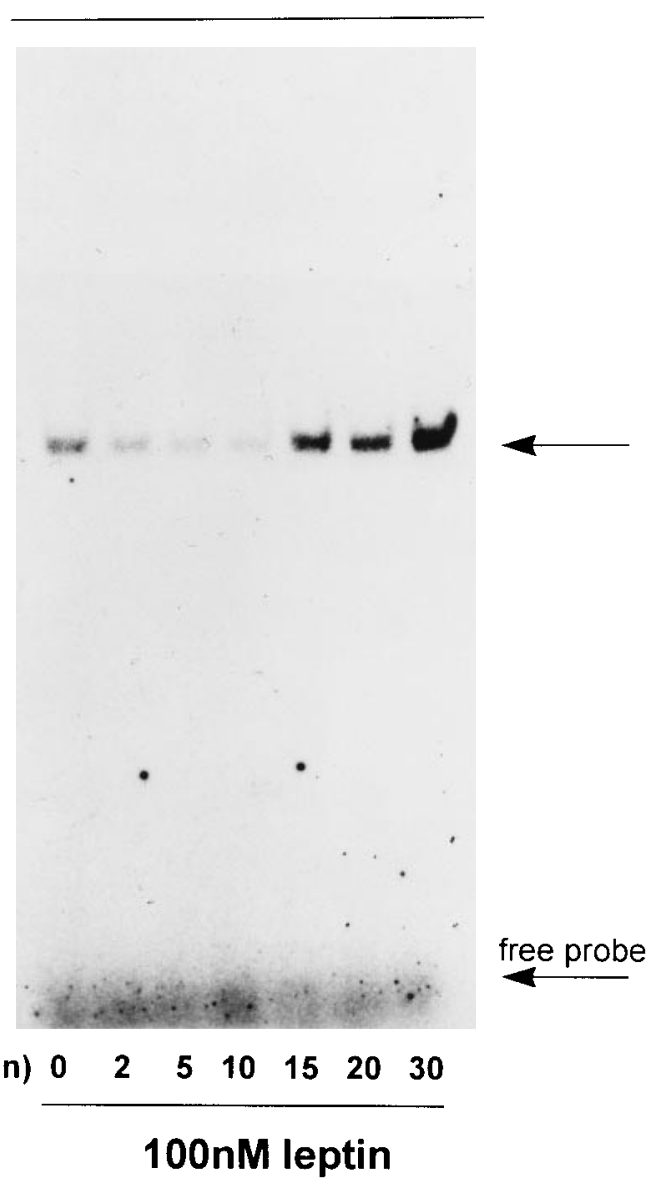

FIGURE 1. Time-dependent induction of STAT DNA binding to the m67SIE element from the c-fos promoter by leptin in RINm5F nuclear extracts. Cells were pre-incubated for $36 \mathrm{~h}$ in serum-free medium and then exposed to leptin $(100 \mathrm{nM})$ for the time indicated below the lanes. Nuclear extracts were isolated and run in a DNA binding assay with end-labelled m67SIE

oligonucleotide. Protein/DNA complexes were separated on a $5 \%$ native PAGE gel. The upper arrow indicates the single complex induced by leptin.

in response to leptin in the cytosol and subsequent nuclear translocation in RINm5F cells. Low levels of STAT3 $\beta$ could be detected after leptin treatment in nuclear extracts of RINm5F cells by 30 min upon longer exposure of the blots (data not shown). Leptin caused nuclear activation of STAT3 $\alpha$ over the concentration range $0 \cdot 2-200 \mathrm{nM}$ in $\mathrm{RINm} 5 \mathrm{~F}$ but STAT3 activation was lost at $2 \mu \mathrm{M}$ leptin in RINm5F cells (Fig. 3b). Leptin treatment of isolated rat pancreatic islets produced an increase in tyrosine phosphorylated STAT3 that peaked by $15 \mathrm{~min}$ and dropped to basal levels by $30 \mathrm{~min}$ in crude islet extracts (Fig. 4, upper gel and graph). The increase in STAT $3 \alpha$ and STAT3 $\beta$ tyrosine phosphorylation was significantly greater at $15 \mathrm{~min}$ than at the 0 time point as normalized to the level of STAT3 detected with an N-terminal-directed STAT3 antibody (Fig. 4 lower gel). (The increase compared with $100 \%$ at 0 time point was: STAT $3 \alpha$, $650 \pm 110 \%, P<0 \cdot 02, n=4 ;$ STAT $3 \beta, 487 \pm 126 \%$, $P<0 \cdot 05, n=4$.) The reference sample in the lower gel of Fig. 4 is from an A431 cell lysate commercially provided as a positive control for STAT3 detection.

\section{Leptin induces transcriptional activation from STAT consensus elements transfected into RINm5F cells}

Leptin increased transcriptional activation from reporter plasmids containing GAS (from the Fc $\gamma$ RI promoter) and IRE (from the human ICAM-1 promoter) STAT-binding elements (Fig. 5). Leptininduced transcriptional activity was greater with the IRE (which has a higher affinity for STAT3) compared with the GAS construct (which has a higher affinity for STAT1) consistent with STAT3 activation (Caldenhoven et al. 1995). Leptin did not induce transcriptional activation of a reporter plasmid driven by the STAT5 consensus element, $\beta$-CAS or the control vector, pBL (Fig. 5).

\section{Leptin-mediated STAT DNA binding is modulated by increases in intracellular cAMP and $\left[\mathrm{Ca}^{2+}\right]_{\mathrm{i}}$}

RINm5F cells were pre-incubated with a number of effectors designed to mimic states of increased metabolic activity for $15 \mathrm{~min}$ and then in the presence of added leptin $(100 \mathrm{nM})$ for a further $15 \mathrm{~min}$ (Fig. 6). As before, leptin alone (100 nM) induced DNA binding of a single STAT complex within $15 \mathrm{~min}$. Acetylcholine $(10 \mu \mathrm{M})$, an endogenous parasympathetic stimulator of insulin secretion, caused a marked reduction in leptin-induced STAT DNA binding to the probe. Pre-incubation of the RINm5F cells with $100 \mathrm{nM}$ phorbol 12-myristate 13-acetate (PMA), a protein kinase $\mathrm{C}$ (PKC) activator, had no significant effect on leptin-induced STAT DNA binding, although it increased c-fos transcript levels in RINm5F as assessed by Northern blot (data not shown). Pre-incubation with the calcium ionophore, ionomycin $(1 \mu \mathrm{g} / \mathrm{ml})$ produced a marked attenuation of leptin-induced STAT DNA binding. Finally, we tested the effects of raising intracellular cAMP by pre-incubating 


\section{Islet nuclear extracts}

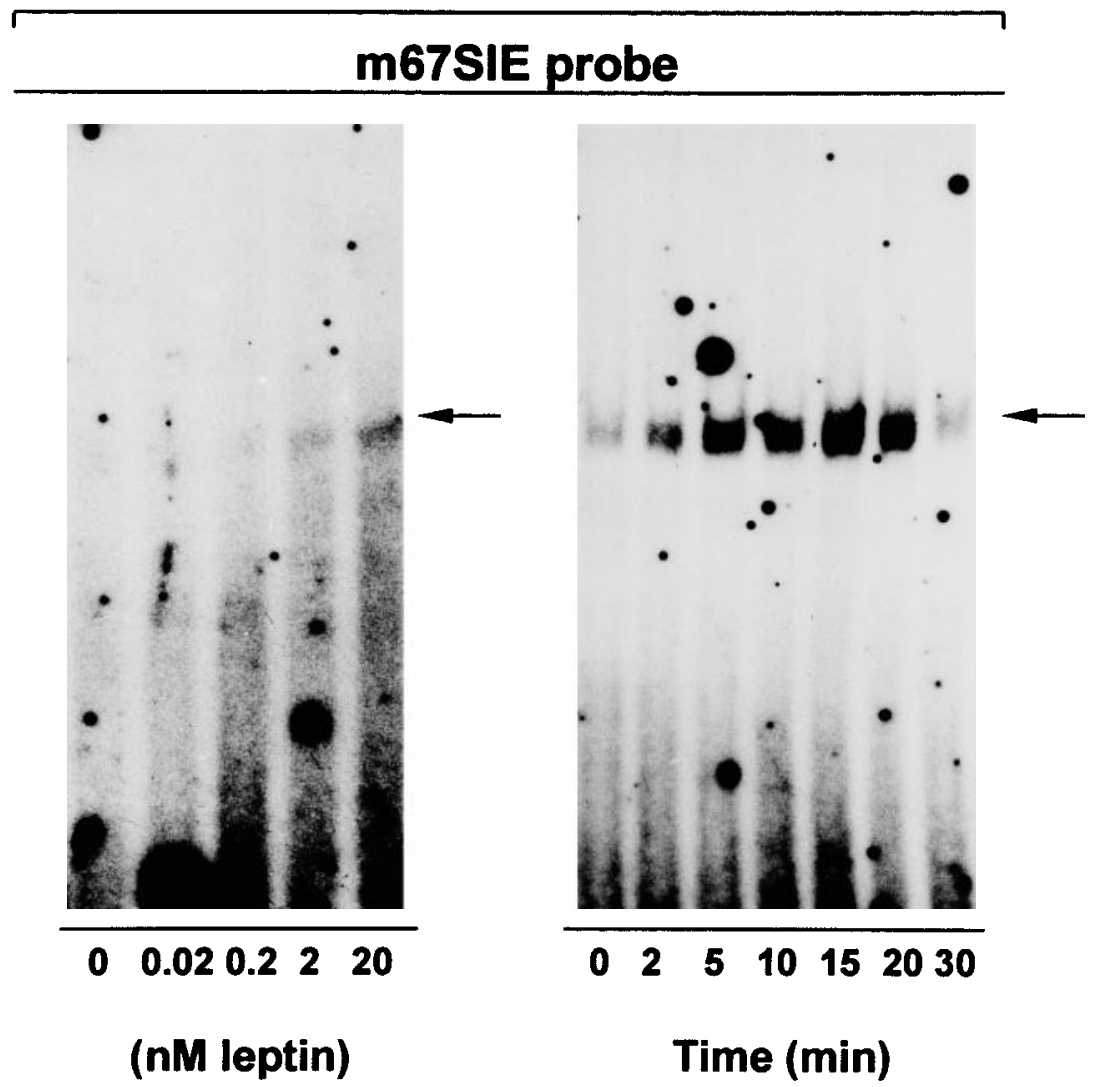

FIGURE 2. Dose- and time-dependent induction of STAT DNA binding to the m67SIE element from the c-fos promoter by leptin in rat islet nuclear extracts. Islets were isolated and pre-incubated for $6 \mathrm{~h}$ in serum-free RPMI-1640 and then exposed to leptin for $15 \mathrm{~min}$ with the leptin concentrations indicated below the lanes (left panel) or to $20 \mathrm{nM}$ leptin for the time indicated below the lane (right panel). Nuclear extracts were then isolated and run in a DNA binding assay with end-labelled m67SIE oligonucleotide. Protein/DNA complexes were separated on a 5\% native PAGE gel. The arrow indicates the single complex induced by leptin.

with both the adenylyl cyclase activator, forskolin $(10 \mu \mathrm{M})$, and the cAMP phosphodiesterase inhibitor, IBMX $(50 \mu \mathrm{M})$. This treatment resulted in a reduction of leptin-induced STAT DNA binding to basal levels; however, this reduction was not as marked as that caused by acetylcholine or ionomycin (Fig. 6).

\section{Increasing cellular metabolic activity does not affect STAT3 tyrosine phosphorylation}

RINm5F nuclear extracts, which had been preincubated with various effectors and then leptin $(100 \mathrm{nM})$ as described above, were probed with the antibody to phospho-Y705 STAT3 (Fig. 7 upper gel) and an anti-N-terminal STAT3 antibody (Fig. 7 lower gel). This revealed that leptin induced STAT3 tyrosine phosphorylation; however, there was no significant change in the tyrosine phosphorylation levels of the STAT3 in response to any of the agents tested.

\section{Leptin increases activated MAP kinase-Y204 levels in RINm5F cells}

Nuclear extracts of leptin-treated RINm5F cells were probed for active MAP kinase with a phospho-Y204-MAP kinase-specific antibody. Leptin caused an increase in the levels of a 44 and $42 \mathrm{kDa}$ MAP kinase-immunoreactive species within 
(a)

RINm5F

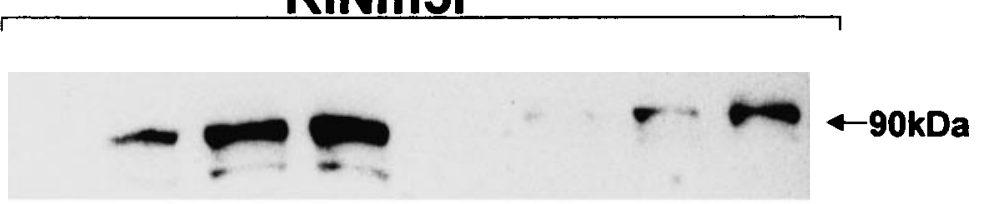

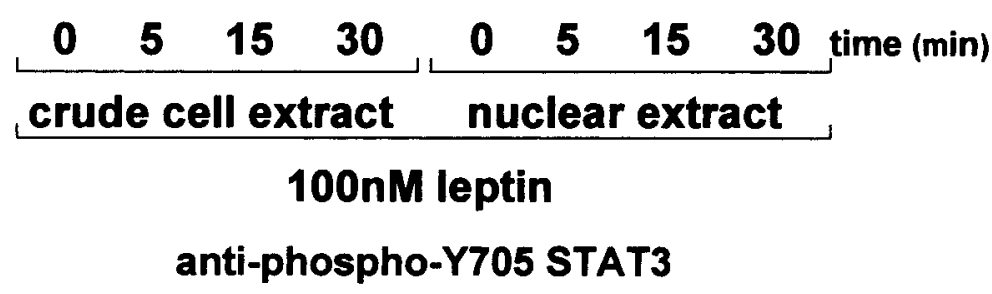

(b)

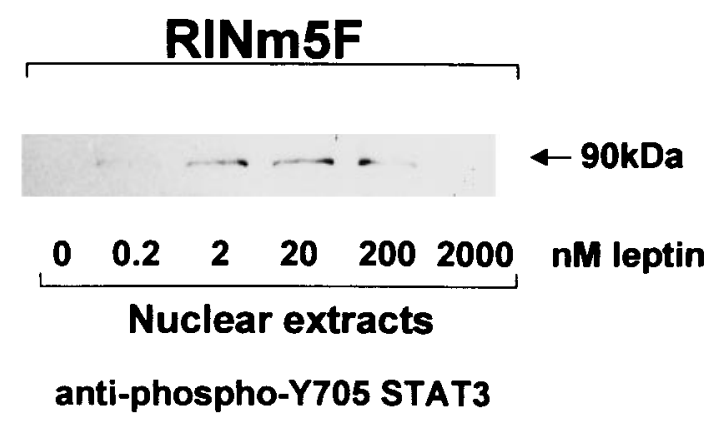

FIGURE 3. Time-dependent induction of tyrosine phosphorylation and nuclear translocation of STAT3 by leptin in RINm5F nuclear extracts. (a) Cells were pre-incubated for $36 \mathrm{~h}$ and then exposed to leptin $(100 \mathrm{nM})$ for the time indicated below the lanes. Leptin caused tyrosine phosphorylation of STAT3 $\alpha$ (this band migrated at approximately $90 \mathrm{kDa}$ and is indicated by an arrow) by $5 \mathrm{~min}$ and STAT3 $\beta$ by $15 \mathrm{~min}$ in crude cell extracts (left panel) that continued to increase until the $30 \mathrm{~min}$ time point. The nuclear translocation of tyrosine phosphorylated STAT3 $\alpha$ was detected in nuclear extracts by 15 min (right panel). (b) RINm5F cells were treated for $15 \mathrm{~min}$ with the concentration of leptin indicated below the lane and the nuclear extracts isolated. Tyrosine phosphorylated nuclear STAT3 $\alpha$ was induced over the concentration range $0 \cdot 2-200 \mathrm{nM}$ leptin.

15 min (Fig. $8 a$ upper gel). The same samples were probed with an antibody that detects ERK1 and ERK2 (anti-panERK) regardless of its activation state (Fig. $8 a$ lower gel). Treatment of isolated rat islets with $20 \mathrm{nM}$ leptin did not lead to an increase in the levels of the active MAP kinase as detected by Western blot (Fig. $8 b$ upper gel). MAP kinase was readily detected in these samples (Fig. $8 b$ lower gel) and tyrosine phosphorylation of STAT3 was detectable in samples prepared in a similar manner for Western analysis (Fig. 4). Treatment of rat islets with concentrations of leptin up to $100 \mathrm{nM}$ did not result in activation of MAP kinase (data not shown). Nuclear extracts of RINm5F from cells treated with $100 \mathrm{nM}$ leptin for $15 \mathrm{~min}$ were used as a positive control in the blots for potential activation of MAP kinase by leptin in pancreatic islets (Fig. 8b).

\section{DISCUSSION}

Pancreatic $\beta$-cell failure is a hallmark of NIDDM (Poitout \& Robertson 1996). A large proportion of patients with NIDDM are also obese (Groop \& 


\section{Islets}

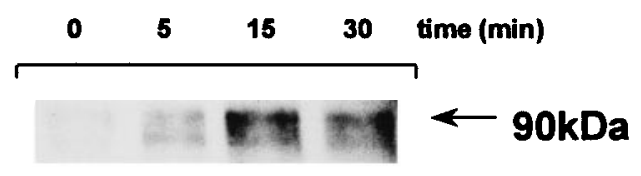

anti-phospho-Y705 STAT3
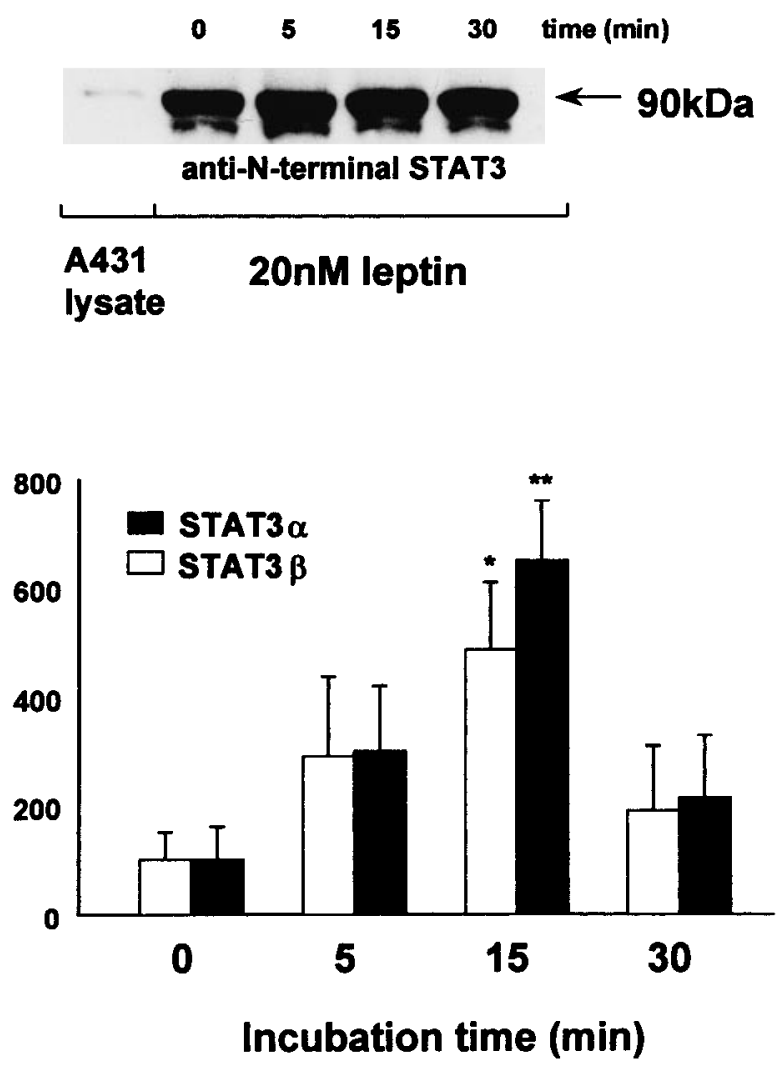

FIGURE 4. Time-dependent induction of STAT3 tyrosine phosphorylation by leptin in isolated rat islets. Rat islets were isolated and pre-incubated for $6 \mathrm{~h}$ in serum-free RPMI-1640 and then exposed to leptin (20 $\mathrm{nM}$ ) for the times indicated above the lanes. Islets were collected by centrifugation, immediately boiled in sample buffer and run on 10\% SDS-PAGE gels. STAT3 was detected with an antibody to activated (phospho-Y705) STAT3 (upper gel) and a STAT3 N-terminal-specific antibody (lower gel). The graph shows a quantification of the time-dependent induction of tyrosine phosphorylation of STAT3 $\alpha$ and STAT3 $\beta$ normalized to the 0 time levels of STAT $3 \alpha$ and STAT3 $\beta$ respectively. Control samples (lower gel, left) are from A431 cell lysates. Results are expressed as mean \pm S.E.M. and statistical significance determined using Student's unpaired $t$-test $(* P<0 \cdot 05$, ** $P<0 \cdot 02$ vs 0 time point $(n=4))$.

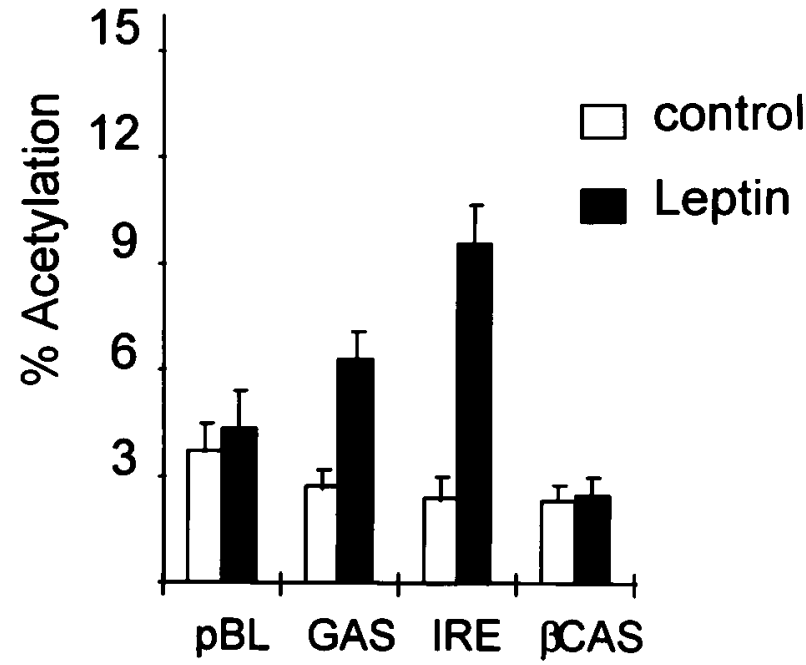

FIGURE 5. Transcriptional activation of reporter constructs driven by STAT element promoters by leptin in RINm5F cells. Cells were transiently transfected with CAT reporter plasmids containing the GAS, IRE or $\beta$-CAS STAT responsive promoter elements. Induction of transcription was most marked from the IRE construct and there was no activation of the STAT5-selective construct. Also shown is the control construct (pBL). Results are mean \pm s.E.M. of three experiments.

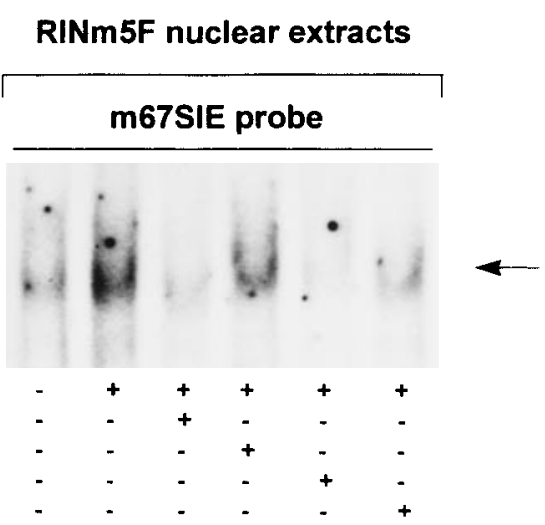

leptin acetylcholine

PMA ionomycin forskolin/IBMX

FIGURE 6. Effect of increasing cellular metabolic activity on leptin-induced STAT DNA binding in RINm5Fcells. RINm5F cells were pre-incubated for $36 \mathrm{~h}$ in serum-free RPMI-1640, 0.1\% BSA. A second 15 min pre-incubation with the effector indicated below the lane was then followed by incubation of the cells with leptin $(100 \mathrm{nM})$ plus the effector for a further 15 min. Nuclear extracts were then isolated as described and run on $5 \%$ native PAGE gels with the end-labelled m67SIE probe. The effectors used were acetylcholine $(10 \mu \mathrm{M})$, PMA $(100 \mathrm{nM})$, ionomycin $(1 \mu \mathrm{g} / \mathrm{ml})$ and forskolin $(10 \mu \mathrm{M}) /$ IBMX $(50 \mu \mathrm{M})$. 


\section{RINm5F nuclear extracts}

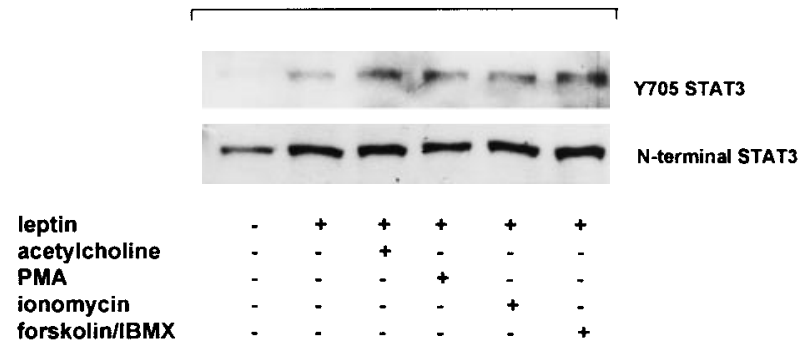

FIGURE 7. Effect of agents that modulate leptin-induced STAT DNA binding on STAT3 tyrosine

phosphorylation. RINm5F cells were pre-incubated for

$36 \mathrm{~h}$ in serum-free RPMI-1640, 0·1\% BSA. A second

15 min pre-incubation with the effector indicated below the lane was then followed by incubation with leptin $(100 \mathrm{nM})$ plus the effector for a further $15 \mathrm{~min}$. Nuclear extracts were isolated and subjected to Western blot and probed with an antibody to activated (Y705) STAT3 (upper gel) and a STAT3 N-terminal-specific antibody (lower gel). The effectors used were acetylcholine $(10 \mu \mathrm{M})$, PMA $(100 \mathrm{nM})$, ionomycin $(1 \mu \mathrm{g} / \mathrm{ml})$ and forskolin $(10 \mu \mathrm{M}) / \mathrm{IBMX}(50 \mu \mathrm{M})$.

Tuomi 1997) and all are insulin resistant. NIDDM develops when compensatory hyperinsulinaemia fails to overcome the insulin resistance. We have suggested previously that the high levels of leptin found in obesity might be one of the factors that precipitates NIDDM through its inhibitory action on the $\beta$-cell (Emilsson et al. 1997, Pallett et al. 1997). We and others have demonstrated that leptin could cause inhibition of insulin secretion from mouse and rat islets (Chen et al. 1997, Emilsson et al. 1997, Fehmann et al. 1997a, Kieffer et al. 1997, Kulkarni et al. 1997, Pallett et al. 1997, Ookooma et al. 1998, Poitout et al. 1998) and a reduction in insulin transcript levels in rat islets (Kulkarni et al. 1997, Pallett et al. 1997). This phenomenon has been shown to involve leptinmediated activation of the ATP-sensitive potassium channels in islets (Kieffer et al. 1997) and insulin-secreting cell lines (Harvey et al. 1997) and a reduction in $\left[\mathrm{Ca}^{2+}\right]_{\mathrm{i}}$ in islets (Fehmann et al. 1997a, Kieffer et al. 1997) and insulin-secreting cell lines (Fehmann et al. 1997a,b). Inhibition of insulin secretion has also been observed in vivo in normal-fed mice and with human islets exposed to physiological levels of leptin in vitro (Kulkarni et al. 1997). Furthermore, chronic leptin exposure leads to islet triglyceride depletion and a loss of nutrient-induced insulin secretion in vivo and in vitro (Koyama et al. 1997, Shimabukuro et al. 1997, Wang et al. 1998). Taken together, this evidence suggests that leptin may have a physiologi- (a)

\section{RINm5F nuclear extracts}

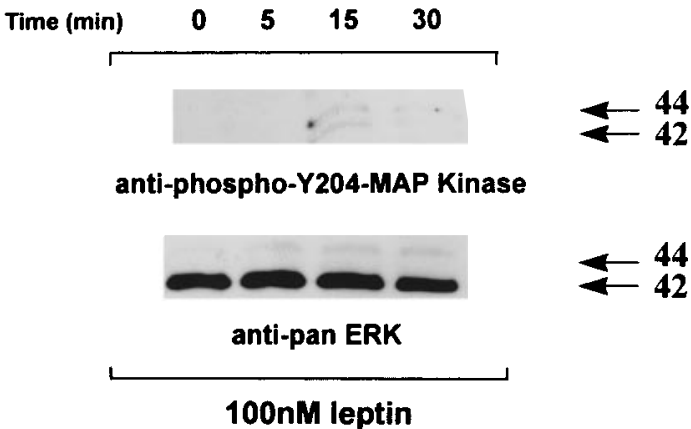

(b)

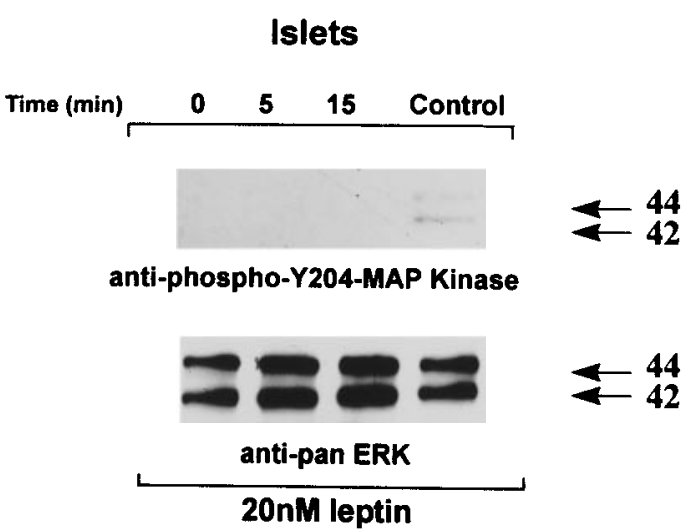

FIGURE 8. Time-dependent induction of MAP kinase p42 and p44 tyrosine phosphorylation by leptin in RINm5F cells but not in rat islets. (a) RINm5F cells were pre-incubated for $36 \mathrm{~h}$ in serum-free RPMI-1640, $0 \cdot 1 \% \mathrm{BSA}$ and then leptin $(100 \mathrm{nM})$ for the time indicated above the lane. Nuclear extracts were then run on $10 \%$ SDS-PAGE gels, transferred to PVDF and probed with an antibody to activated (Y204) MAP kinase (upper gel) and an anti-panERK (lower gel) antibody. Leptin caused an increase in the tyrosine phosphorylated MAP kinases that was detectable by $15 \mathrm{~min}$ and dropped by $30 \mathrm{~min}$ of incubation. (b) Isolated rat islets were pre-incubated for $6 \mathrm{~h}$ and then exposed to leptin $(20 \mathrm{nM})$ for the times indicated above the lane. Crude protein extracts were then probed with the (Y204) MAP kinase (upper gel) and anti-panERK (lower gel) antibodies. The arrows indicate the apparent molecular masses of the bands. Nuclear extracts of RINm5F from cells treated with $100 \mathrm{nM}$ leptin for 15 min were used as positive control in the blots for the potential activation of MAP kinase by leptin in pancreatic islets.

cal influence on the normal glucose-sensing mechanism of the pancreatic $\beta$-cell. However, it is also clear that many obese subjects with high circulating 
leptin concentrations are not diabetic and animal studies show that exogenously administered leptin generally improves insulin action in obese animals. Thus it seems that the potential diabetogenic activity of leptin is modified by differential efficacy of the leptin signalling pathways in various tissues. The role of leptin signalling through $\mathrm{OB}-\mathrm{Rb}$ in the long-term control of pancreatic $\beta$-cell metabolism and gene expression ( $\beta$-cell programming) is currently unclear.

The full-length leptin receptor, OB- $\mathrm{Rb}$ (Chen et al. 1996), is closely related to the type I superfamily of cytokine receptors (Tartaglia et al. 1995). OB-Rb is known to homodimerize (White et al. 1997) and to activate JAK2 (Ghilardi \& Skoda 1997) and STATs 1, 3 and 5B (Baumann et al. 1996) or 3, 5 and 6 (Ghilardi et al. 1996) in in vitro overexpression systems. In vivo, the activation pattern appears more restricted. Indeed, despite the availability of STATs 1, 3, 5 and 6, leptin appears to activate only STAT3 in the hypothalamus (Vaisse et al. 1996), STAT1 in adipose tissue (Siegrist-Kaiser et al. 1997) and STAT5 in the small intestine (Morton et al. 1998). We find that leptin activates STAT3 in isolated rat islets where approximately $80 \%$ of the cell population are $\beta$-cells (Orci 1986). A STAT3 signalling mechanism in the $\beta$-cell is corroborated by activation of STAT3 in nuclear extracts of RINm5 cells, a rat clonal pancreatic $\beta$-cell model that we have shown previously responds to leptin and expresses high levels of OB-Rb (Islam et al. 1997). Although STAT1 and 5 were detected in both isolated rat islets and RINm5F, we did not detect activation of either molecule in response to leptin treatment by probing with a specific antibody to phospho-Y701 STAT1 or using a STAT5-selective $\beta$-casein oligonucleotide (data not shown). We also did not detect transcriptional activation of a reporter construct linked to the $\beta$-casein element. It is therefore likely that the leptin signal is transmitted by different STATs depending on the target tissue, time frame and cellular system under study. We also show that leptin can cause induction of transcription from reporter constructs with STAT3-responsive promoter elements in RINm5F. This indicates that STAT3 activation leads directly to transcriptional activation and provides evidence of the first stages of $\beta$-cell programming by leptin through STAT3. The time-course for induction of STAT $3 \alpha$ and STAT3 $\beta$ appears to be more rapid in the primary islet compared with the RINm5F cell. This may be relevant for the kinetics of gene activation in primary $\beta$-cells versus clonal $\beta$-cells. The delayed activation and nuclear translocation of STAT3 $\beta$ seen in RINm5F cells may also have important consequences, since STAT3 $\alpha$ and STAT3 $\beta$ are reported to have different functional roles in controlling gene expression (Caldenhoven et al. 1996, Schaeffer et al. 1997). The concentrations of leptin that elicit STAT activation fall within the physiological range (Maffei et al. 1995). Thus, induction of STAT DNA binding is detectable in isolated rat islet nuclear extracts with $2 \mathrm{nM}$ leptin and STAT3 activation is observed at concentrations as low as $0.2 \mathrm{nM}$ leptin in RINm5F nuclear extracts. This supports a role for leptin in modulation of $\beta$-cell function under normal physiological conditions. An extreme concentration $(2 \mu \mathrm{M})$ of leptin led to a loss of nuclear STAT3 activation as assessed by Western blot and may represent saturation of leptin receptor binding as we found previously for the U-shaped dose-dependent inhibition of insulin secretion (Pallett et al. 1997).

The insulin synthesis and secretory mechanism of the pancreatic $\beta$-cell are controlled by membrane depolarization and calcium influx due to nutrient metabolism (Prentki et al. 1997). This process is potentiated by hormone-mediated elevation of intracellular second messengers such as cAMP (Ammälä et al. 1993, Holz et al. 1993) and D-myo-inositol 1,4,5-trisphosphate (IP3) (Zawalich \& Zawalich 1996). We have assessed the impact of increased metabolic activity on leptin-inducible STAT DNA binding activity and STAT3 tyrosine phosphorylation in a clonal insulin-secreting cell line that we had found to respond functionally to leptin (Islam et al. 1997). Although RINm5F cells lack the cellular machinery that allows them to respond to glucose (Praz et al. 1983), these cells retain many of the features of regulated insulin release and have been used extensively as a model of the pancreatic $\beta$-cell. The lack of glucose responsiveness in the RINm5F cells was circumvented by experimental approaches using pharmacological agents that mimic the raised metabolic activity found in native $\beta$-cells upon exposure to glucose and hormonal stimuli. Increased $\left[\mathrm{Ca}^{2+}\right]_{\mathrm{i}}$ is known to be one of the major events that occurs after the exposure of normal $\beta$-cells to stimulatory concentrations of nutrients, primarily glucose, and hormonal stimuli (Zawalich \& Zawalich 1996, Gromada et al. 1997, Prentki et al. 1997). Raising $\left[\mathrm{Ca}^{2+}\right]_{\mathrm{i}}$ with the calcium ionophore ionomycin leads to a marked reduction in leptin-inducible STAT DNA binding to the m67SIE probe. This could be interpreted as evidence that raised metabolic activity attenuates leptin signalling in $\beta$-cells and is consistent with a counteraction of the reduction of $\left[\mathrm{Ca}^{2+}\right]_{\mathrm{i}}$ ascribed to leptin (Fehmann et al. 1997a, Kieffer et al. 1997, Kulkarni et al. 1997). It should be noted, however, that raising intracellular calcium with ionomycin 
does not allow discrimination between extracellular and intracellular sources of calcium. We also exposed RINm5F to forskolin and IBMX, compounds that activate adenylyl cyclase and inhibit cAMP phosphodiesterases respectively. These agents raise intracellular cAMP, a second messenger that can potentiate insulin secretion (Ammölö et al. 1993, Holz et al. 1993, Gromada et al. 1997). The RINm5F cell has been reported to secrete insulin in response to increased cAMP through a calciumindependent mechanism (Wollheim et al. 1984), whereas intact rat $\beta$-cells exhibit calcium-dependent cAMP-inducible insulin secretion (Holz et al. 1993). Increasing cAMP resulted in a reduction of leptin-induced STAT DNA binding to basal levels in RINm5F cell nuclear extracts. Since the cAMP response in RINm5F is believed to be uncoupled from increased $\left[\mathrm{Ca}^{2+}\right]_{i}$, this could imply a role for cAMP-dependent protein kinase (PKA) in negative modulation of leptin signalling. Agents that raise $\beta$-cell metabolic activity by this mechanism, such as the insulinotropic hormone, GLP-1, may counteract leptin signalling by a combined increase in PKA activity and raised $\left[\mathrm{Ca}^{2+}\right]_{\mathrm{i}}$ in native rat $\beta$-cells (Holz et al. 1993, Gromada et al. 1997). Reversal of leptin-mediated inhibition of insulin secretion by GLP-1 has also been observed (Fehmann et al. 1997b). The activation of calcium-dependent protein kinases (PKCs) is another event associated with increased metabolic activity in $\beta$-cells. Glucose metabolism (Easom et al. 1989) and exposure of the $\beta$-cell to stimuli such as the parasympathetic neurotransmitter, acetylcholine (Zawalich \& Zawalich 1996), lead to increased activation of $\mathrm{PKC}$, increased $\left[\mathrm{Ca}^{2+}\right]_{\mathrm{i}}$ and an increase in insulin secretion. We exposed RINm5F cells to both the PKC agonist, PMA, and acetylcholine. Activation of PKC alone did not affect leptin-inducible STAT DNA binding. In contrast, acetylcholine caused a marked reduction in leptin-induced STAT DNA binding that could be due to the rapid increase in intracellular calcium released from internal stores in response to production of the second messenger, IP3, by this neurotransmitter (Zawalich \& Zawalich 1996). The lack of effect of direct PKC activation by PMA on STAT DNA binding indicates that a PKC-linked mechanism of raising intracellular calcium, as has been described in RINm5F cells (Yada et al. 1989), does not contribute to a reduction in leptin-inducible STAT DNA binding in this cell line under the conditions tested. The present information supports a role for raised intracellular calcium, as opposed to direct action of PKC in the attenuation of leptin-mediated STAT DNA binding activity. This does not, however, rule out modulation of STAT3 activation through a
PKC-mediated change in serine phosphorylation as has been reported by others to occur (Yang et al. 1996). The leptin-deficient $o b / o b$ mouse is characterized by hyperinsulinaemia due to an exaggerated PKC-linked sensitivity at the $\beta$-cell level (Chen \& Romsos 1997) that can be 'corrected' by leptin treatment of $o b / o b$ islets (Chen et al. 1997). Increased parasympathetic stimuli or exposure to other hormones that act through raising intracellular calcium (for example cholecystokinin and vasopressin) are therefore also likely to counteract $\mathrm{OB}-\mathrm{Rb}$-mediated signalling in the $\beta$-cell. Attenuation of the inhibitory programming of the $\beta$-cell by leptin could therefore contribute to the hyperinsulinaemia associated with a raised parasympathetic tone found in some forms of obesity (Bray et al. 1990). We did not detect any change in tyrosine phosphorylation of STAT3 in response to any of the effectors tested. This implies that events downstream of STAT activation by JAKs are a target for modulation by these agents.

We have also recently found that leptin can induce the immediate-early gene, c-fos, in RINm5F and that this precedes a proliferative response (Islam et al. 1997). A similar MAP kinasedependent effect has subsequently been observed in the MIN-6 $\beta$-cell line (Tanabe et al. 1997). In the current studies we find a leptin-mediated increase in the levels of active MAP kinase isoforms in RINm5F cells but not in adult primary rat islets. One interpretation of these data is that leptin may have a role in controlling the early development and growth/differentiation of islet $\beta$-cells in discrete sub-populations. We proposed previously that high levels of leptin might contribute to the $\beta$-cell hyperplasia and hypertrophy associated with obesity by affecting this process in some way (Islam et al. 1997). Alternatively, activation of MAP kinase activity in $\beta$-cells may be involved in the modulation of STAT signalling. Thus, MAP kinase is known to serine phosphorylate STAT3 leading to a modulation of its DNA-binding activity (Chung et al. 1997).

The present study implicates signalling through STAT3 as a likely mechanism whereby regulation of gene expression in the $\beta$-cell is modulated by leptin. STAT3 activation has been associated with diverse phenomena such as cell transformation (Karras et al. 1997, Turkson et al. 1998) and differentiation (Minami et al. 1996) and is also the target for leptin action in the hypothalamus in vivo (Vaisse et al. 1996). The sub-set of target genes under the influence of leptin-inducible STAT3 in $\beta$-cells is therefore an important area of future study. Leptin-mediated proliferation of clonal $\beta$-cells (Islam et al. 1997, Tanabe et al. 1997) and 
cells of haematopoietic origin (Gainsford et al. 1996) associated with MAP kinase activity have also been described. However, since we did not find a similar activation of MAP kinase in isolated rat islets, this could mean that MAP kinase is not a major pathway involved in the regulation of primary $\beta$-cell function by leptin. Finally, our observation that raising intracellular calcium and cAMP interferes with leptin signalling suggests that raised metabolic activity may counteract leptin-inducible DNA binding of STAT3 in the $\beta$-cell. Since leptin may have a physiological inhibitory role in the regulation of $\beta$-cell responses to nutrients and other stimuli, chronic hyperglycaemia, inappropriate hormonal stimuli or insensitivity to leptin action such as that found in obese individuals could contribute to hyperinsulinaemia at early stages in the transition from obesity to NIDDM. Subsequently, perhaps during conditions of $\beta$-cell glucose desensitization and glucose toxicity, as is postulated to occur in NIDDM (Poitout \& Robertson 1996), the high plasma leptin levels in obese individuals may become diabetogenic.

\section{ACKNOWLEDGEMENTS}

We thank Amber Kanu and David Hislop for technical assistance. N M M was supported by a studentship from Société de Conseils de Recherches et d'Applications Scientifiques, Paris 75016, France.

\section{REFERENCES}

Ammälä C, Ashcroft FM \& Rorsman P 1993 Calciumindependent potentiation of insulin release by cyclic AMP in single $\beta$-cells. Nature 363 356-358.

Baumann H, Morella KK, White DW, Dembski M, Bailon PS, Kim H, Lai C-F \& Tartaglia LA 1996 The full-length leptin receptor has signaling capabilities of interleukin 6-type cytokine receptors. Proceedings of the National Academy of Sciences of the USA 93 8374-8379.

Bray GA, Fisler J \& York DA 1990 Neuroendocrine control of the development of obesity: understanding gained from studies of experimental animal models. Frontiers in Neuroendocrinology 11 128-181.

Caldenhoven E, van Dijk T, Raaijmakers JAM, Lammers J-WJ, Koenderman L \& de Groot RP 1995 Activation of the STAT3/acute phase response factor transcription factor by interleukin-5. Fournal of Biological Chemistry 270 25778-25784.

Caldenhoven E, van Dijk TB, Solari R, Armstrong J, Raaijmakers JAM, Lammers JWJ, Koenderman L \& de Groot RP 1996 STAT3-beta, a splice variant of transcription factor STAT3, is a dominant negative regulator of transcription. Fournal of Biological Chemistry 271 13221-13227.

Campfield LA, Smith FJ, Guisez Y, Davos R \& Burn P 1995 Recombinant mouse OB protein: evidence for a peripheral signal linking adiposity and central neural networks. Science $269546-549$.

Chen N \& Romsos DR 1997 Persistently enhanced sensitivity of pancreatic islets from $o b / o b$ mice to PKC-stimulated insulin secretion. American Fournal of Physiology 272 (Endocrinology and Metabolism 35) E304-E311.

Chen H, Charlat O, Tartaglia LA, Woolf EA, Weng X, Ellis SJ, Lakey ND, Culpepper J, Moore KJ, Breibart RE, Duyk GM, Tepper RI \& Morgenstern JP 1996 Evidence that the diabetes gene encodes the leptin receptor - identification of a mutation in the leptin receptor gene in $d b / d b$ mice. Cell $\mathbf{8 4}$ 491-495.

Chen NG, Swick AG \& Romsos DR 1997 Leptin constrains acetylcholine-induced insulin secretion from pancreatic islets of ob/ob mice. Fournal of Clinical Investigation 100 1174-1179.

Chung J, Uchida E, Grammer TC \& Blenis J 1997 STAT3 serine phosphorylation by ERK-dependent and -independent pathways negatively modulates its tyrosine phosphorylation. Molecular and Cellular Biology 17 6508-6516.

Coleman DL 1978 Obese and diabetes: two mutant genes causing diabetes-obesity syndromes in mice. Diabetologia 14 141-148.

Easom RA, Hughes JH, Landt M, Wolf BA, Turk J \& McDaniel ML 1989 Comparison of effect of phorbol esters and glucose on protein kinase $\mathrm{C}$ activation and insulin secretion in pancreatic islets. Biochemical fournal 264 27-33.

Emilsson V, Liu Y-L, Cawthorne MA, Morton NM \& Davenport M 1997 Expression of the functional leptin receptor mRNA in pancreatic islets and direct inhibitory action of leptin on insulin secretion. Diabetes 46 313-316.

Fehmann H-C, Peiser C, Bode H-P, Stamm M, Staats P, Hedetoft C, Lang RE \& Goke B $1997 a$ Leptin: a potent inhibitor of insulin secretion. Peptides 18 1267-1273.

Fehmann H-C, Bode H-P, Ebert T, Karl A \& Goke B $1997 b$ Interaction of GLP-1 and leptin at rat pancreatic $\beta$-cells: effects on insulin secretion and signal transduction. Hormone and Metabolic Research 29 572-576.

Gainsford T, Willson TA, Metcalf D, Handman E, McFarlane C, Ng A, Nicola NA, Alexander WS \& Hilton DJ 1996 Leptin can produce proliferation, differentiation, and functional activation of hemopoietic cells. Proceedings of the National Academy of Sciences of the USA 93 14564-14568.

Ghilardi N \& Skoda RC 1997 The leptin receptor activates Janus kinase 2 and signals for proliferation in a factordependent cell line. Molecular Endocrinology 11 393-399.

Ghilardi N, Ziegler S, Wiestner A, Stoffel R, Heim MH \& Skoda RC 1996 Defective STAT signaling by the leptin receptor in diabetic mice. Proceedings of the National Academy of Sciences of the USA 93 6231-6235.

Gromada J, Ding WG, Barg S, Renstrom E \& Rorsman P 1997 Multisite regulation of insulin secretion by cAMP-increasing agonists - evidence that glucagon-like peptide 1 and glucagon act via distinct receptors. European fournal of Physiology 434 515-524.

Groop LC \& Tuomi T 1997 Non-insulin-dependent-diabetes mellitus - a collision between thrifty genes and an affluent society. Annals of Medicine 29 37-53.

Halaas JL, Gajiwala KS, Maffei M, Cohen SL, Chait BT, Rabinowitz D, Lallone RL, Burley SK \& Friedman JM 1995 Weight-reducing effects of the plasma protein encoded by the obese gene. Science $269543-546$.

Harvey J, McKenna F, Herson PS, Spanswick D \& Ashford MLJ 1997 Leptin activates ATP-sensitive channels in the rat insulin-secreting cell line, CRI-G1. Fournal of Physiology 504 $527-535$.

Holz GG, Kuhtreiber WM \& Habener JF 1993 Pancreatic beta cells are rendered glucose-competent by the insulinotropic hormone glucagon-like peptide $1(7-37)$. Nature 361 $362-365$. 
Islam MS, Morton NM, Hansson A \& Emilsson V 1997 Rat insulinoma-derived pancreatic $\beta$-cells express a functional leptin receptor that mediates a proliferative response. Biochemical and Biophysical Research Communications 238 851-855.

Karras JG, Wang ZH, Huo L, Howard RG, Frank DA \& Rothstein TL 1997 Signal transducer and activator of transcription-3 (STAT-3) is constitutively activated in normal, self-renewing B-1 cells but only inducibly expressed in conventional B lymphocytes. Fournal of Experimental Medicine 185 1035-1042.

Kieffer TJ, Heller RS, Leech CA, Holz GG \& Habener JF 1997 Leptin suppression of insulin secretion by the activation of ATP-sensitive $\mathrm{K}^{+}$channels in pancreatic $\beta$-cells. Diabetes 46 1087-1093.

Koyama K, Chen GX, Wang MY, Lee Y, Shimabukuro M, Newgard CB \& Unger RH 1997 Beta-cell function in normal rats made chronically hyperleptinemic by adenovirus-leptin gene therapy. Diabetes 46 1276-1280.

Kulkarni RN, Wang ZL, Wang RM, Hurley JD, Smith DM, Ghatei MA, Withers DJ, Gardiner JV, Bailey CJ \& Bloom SR 1997 Leptin rapidly suppresses insulin release from insulinoma cells, rat and human islets and, in vivo, in mice. Fournal of Clinical Investigation 100 2729-2736.

Maffei M, Halaas J, Ravussin E, Pratley RE, Lee GH, Zhang Y, Fei H, Kim S, Lallone R, Ranganathan S, Kern PA \& Friedman JM 1995 Leptin levels in human and rodent measurement of plasma leptin and OB RNA in obese and weight-reduced subjects. Nature Medicine 1 1155-1161.

Minami M, Inoue M, Wei S, Takeda K, Matsumoto M, Kishimoto T \& Akira S 1996 STAT3 activation is a critical step in gp-130-mediated terminal differentiation and growth arrest of a myeloid cell line. Proceedings of the National Academy of Sciences of the USA 93 3963-3966.

Morton NM, Emilsson Liu Y-L \& Cawthorne MA 1998 Leptin action in intestinal cells. Fournal of Biological Chemistry 273 26194-26201.

Ookooma M, Ookooma K \& York DA 1998 Effects of leptin on insulin secretion from isolated rat pancreatic islets. Diabetes 47 219-223.

Orci L 1986 The insulin cell: its cellular environment and how it processes (pro)insulin. Diabetes Metabolism Reviews 2 71-106.

Pallett AL, Morton NM, Emilsson V \& Cawthorne MA 1997 Leptin inhibits insulin secretion and reduces insulin mRNA levels in rat isolated pancreatic islets. Biochemical and Biophysical Research Communications 238 267-270.

Pelleymounter MA, Cullen MJ, Baker MB, Hecht R, Winters D, Boone T \& Collins F 1995 Effects of the obese gene product on body weight regulation in $o b / o b$ mice. Science 269 540-543.

Poitout V \& Robertson RP 1996 An integrated view of beta cell dysfunction in type II diabetes. Annual Review of Medicine 47 69-83.

Poitout V, Rouault C, Guerre-Millo M, Briaud I \& Reach G 1998 Inhibition of insulin secretion by leptin in normal rodent islets of Langerhans. Endocrinology 139 822-826.

Praz GA, Halban PA, Wollheim CB, Blondel B, Strauss AJ \& Renold AE 1983 Regulation of immunoreactive insulin release from a rat cell line (RINm5F). Biochemical fournal $210345-352$

Prentki M, Tornheim K \& Corkey BE 1997 Signal transduction mechanisms in nutrient-induced insulin secretion.

Diabetologia 40 S32-S41.
Schaeffer TS, Sanders LK, Park OK \& Nathans D 1997 Functional differences between STAT $3 \alpha$ and STAT3 $\beta$. Molecular and Cellular Biology 17 5307-5316.

Shimabukuro M, Koyama K, Chan GX, Wang MY, Trieu F, Lee Y, Newgard CB \& Unger RH 1997 Direct antidiabetic effect of leptin through triglyceride depletion of tissues. Proceedings of the National Academy of Sciences of the USA 94 4637-4641.

Siegrist-Kaiser CA, Pauli V, Juge-Aubry CE, Boss O, Pernin A, Chin WW, Cusin I, Rohner-Leanrenaud F, Burger AG, Zapf J \& Meier CA 1997 Direct effects of leptin on brown and white adipose tissue. Fournal of Clinical Investigation 100 $2858-2864$.

Tanabe K, Okuya S, Tanizawa Y, Matsutani A \& Oka Y 1997 Leptin induces proliferation of pancreatic beta cell line MIN6 through activation of mitogen-activated protein kinase. Biochemical and Biophysical Research Communications 241 765-768.

Tartaglia LA, Dembski M, Wen X, Deng N, Culpepper J, Devos R, Richards GJ, Campfield LA, Clark FT, Deeds J, Muir C, Sanker S, Moriarty A, Moore KJ, Smutko JS, Mays GG, Woolf EA, Monroe CA \& Tepper RI 1995 Identification and expression cloning of a leptin receptor OB-R. Cell 83 1263-1271.

Turkson J, Bowman T, Garcia R, Caldenhoven E, DeGroot RP \& Jove R 1998 STAT3 activation by src induces specific gene regulation and is required for cell transformation. Molecular and Cellular Biology 18 2545-2552.

Vaisse C, Halaas JL, Horvath CM, Darnell JE Jr, Stoffel M \& Friedman JM 1996 Leptin activation of Stat3 in the hypothalamus of wildtype and $o b / o b$ mice but not $d b / d b$ mice. Nature Genetics 14 95-97.

Wang M-Y, Koyama K, Shimabukuro M, Newgard CB \& Unger RH 1998 OB-Rb gene transfer to leptin-resistant islets reverses diabetogenic phenotype. Proceedings of the National Academy of Sciences of the USA 95 714-718.

White DW, Kuropatwinski KK, Devos R, Baumann H \& Tartaglia LA 1997 Leptin receptor (OB-R) signaling cytoplasmic domain mutational analysis and evidence for receptor homo-oligomerisation. Fournal of Biological Chemistry 272 4065-4071.

Wollheim CB, Ullrich S \& Pozzan T 1984 Glyceraldehyde, but not cyclic AMP-stimulated insulin release is preceded by a rise in free $\mathrm{Ca}^{2+}$. FEBS Letters 177 17-22.

Yada T, Ruso LL \& Sharp WG 1989 Phorbol ester-stimulated insulin secretion by RINm5F insulinoma cells is linked with membrane depolarisation and an increase in cytosolic free $\mathrm{Ca}^{2+}$ concentration. Fournal of Biological Chemistry 264 $2455-2462$.

Yang CH, Shi W, Basu L, Murti A, Constantinescu SN, Blatt L, Croze E, Mullersman JE \& Pfeffer LM 1996 Direct association of STAT3 with the IFNAR-1 chain of the human type I interferon receptor. Fournal of Biological Chemistry 271 8057-8061.

Zawalich WS \& Zawalich KC 1996 Regulation of insulin secretion by phospholipase C. American Fournal of Physiology 271 (Endocrinology and Metabolism 34) E409-E416.

Zhang Y, Proenca R, Maffei M, Barone M, Leopold L \& Friedman J 1994 Positional cloning of the mouse obese gene and its human homologue. Nature 372 425-432.

REVISED MANUSCRIPT RECEIVED 15 October 1998 